\title{
Public Relations as a Defense Mechanism Against Discriminatory Propaganda
}

\section{Ayrımcı Propaganda Faaliyetlerine Karşı Bir Savunma Mekanizması Olarak Halkla Illişkiler}

Simge ÜNLÜ KURT ${ }^{1}$

https://orcid.org/0000-0002-0137-4210

\begin{abstract}
The purpose of this study is to examine the propaganda against "marginal" organizations and individuals and how these organizations/individuals can use the methods and tools of public relations in the anti-propaganda process. In this context, firstly homophobic propaganda will be discussed as a type of discriminatory propaganda, and then prejudices and stereotypes against homosexuals will be examined with their reasons, usages, sub-themes and various examples. In the public relations section of the study, defending tactics and strategies against propaganda activities will be given in the topics of message strategy, persuasion, target audience analysis, research process, image and reputation management.
\end{abstract}

Keywords: Discrimination, Homophobia, Propaganda, Public Relations, Strategy

\section{INTRODUCTION}

Public relations studies show that; people, institutions and organizations use the processes of discipline with sub-applications such as image management, corporate identity, crisis and issue management. However, lack of institutional mechanisms for protecting mariginal community and individuals (which are being represented at the level of civil society organization) against propaganda activities -that involve prejudice and discrimination against them- can be seen. Therefore, the problem that arises in this phase is; can Public Relations fulfill this function as a defense mechanism?

In the past, Public Relations carried out its mission only as a promotional tool, but as we approach the

\begin{abstract}
ÖZET
Bu çalışmanın amacı "marjinal" organizasyonlar ve bireylere karşı yürütülen propaganda çalışmalarında halkla ilişkiler yöntem ve araçlarını nasıl bir savunma aracı olarak kullanılabileceğinin sunulmasıdır. $\mathrm{Bu}$ doğrultuda ayrımcı propaganda çalışmaları; kaynaklanma sebepleri, kullanım gerekçeleri, alt temaları ve çeşitli örnekleri ile incelenmiştir. Çalışmanın halkla ilişkilere bölümünde ise; imaj ve itibar yönetimi, araştırma süreci, hedef kitle analizi, mesaj stratejisi ve ikna gibi konular bağlamında propaganda faaliyetlerine karşı kullanılabilecek taktik ve stratejiler aktarılmıştır.
\end{abstract}

Anahtar Kelimeler: Halkla Ilişkiler, Ayrımcılığa Karşı Propaganda, Stareteji. 21st century, understanding of PR transformed with excellence theory and human-focused approaches. Public Relations has become a management function which plays an effective role in management decisions, stakeholder relations, and most importantly contributing both the society and the institution itself (Grunig and Hunt, 1984). Thereby ensuring the fulfillment of institutional citizenship duties in addition to being the organizer of the message strategies in crises, promotional tool of products and services or the whole of image, PR is no longer just a collection of ideas stuck in the institution. Public relations has become a holistic system of thinking and management philosophy which supports and triggers the ideas, innovations, and 
initiatives that have grown in society for growing and developing together.

Especially two-way communication function and the diversification of the target group; the role of public relations, such as raising awareness, developing relationships, and addressing social problems has begun to gain importance. In this study instead of making inferences from a hypothesis such as "Institutions need to be more sensitive to marginal groups through their public relations campaings', the study will answer the following question: "How can these groups defend themselves and their rights through PR?".

In this direction; as a marginal group LGBT organizations have discussed based on how social influence can be created through public relations, what steps should be taken in the path of institutionalization, at what levels lobbying activities can be used effectively, the importance of informing the public and monologism and how to create an environment to struggle against propaganda.

\section{HOMOPHOBIC PROPAGANDA AS A TYPE OF DISCRIMINATORY PROPAGANDA}

Bluemenfeld (1992, p. 15) describes heterosexualism as a structure of thought that only sees heterosexual relationships as acceptable sexual tendency and believes it to be so. Those who have this tendency to feel closeness and sexual desire to people of their own gender, could hated by heterosexual peoples. This structure of thought and fear-hate chain feeds the formation of an environment of prejudice and discrimination against LGBT individuals in modern society. This mindset especially is the main idea of the anti-gay organizations and their propaganda activities. Leaders of such organizations portray homosexuals as a threat to the society.

Homophobia refers to negative emotions and negative behaviors directed towards homosexuality and towards to people with sexual orientation called "lesbian", "gay", "bisexual","transsexual” (LGBT) (Renzetti and Edleson, 2008, p. 338). Homophobia manifests itself with emotions such as prejudice, hatred and repulsion. These emotions could arise from different reasons such as psychology, culture and religious beliefs (McCormack, 2013, p. 35).

Homophobic propaganda (or anti-homosexual propaganda) could be described as conveying negative opinions by various propaganda techniques. These practices are conducted through anti-homosexual prejudices and stereotypes (Stangor, 2000). The term was used first by historian Stefan Micheler in his article "Homophobic Propaganda and the Denunciation of Same-Sex-Desiring Men under National Socialism" (Micheleri, 2002, p. 105).

Homophobic propaganda uses humiliating and degrading statements against homosexuals with religious, medical or moral grounds. For example, accusations of child abuse frequently used in the modern era (Dailey, 2002). Other methods consist of accusations directed against homosexuality as being against; traditional values, the religion and as a sexual perversion to destroying the families. These negative opinions regarding homosexual desire and relation are evident throughout history and show differences from culture to culture (CTV News, 2013).

Negative propaganda against homosexuality can be gathered under different subheadings. These are studies considering that homosexuality; is not natural, related to child abuse, is a sin and HIV is a homosexual disease (Zimmerman and Haggerty, 2003).

Opinions on homosexuality is not natural and that it is a disease, are seen even during the time of Plato. Homosexuality has been considered as a disease for a long time till the 20th century, together with some opinions saying that it is not natural and it is even equivalent to cannibalism (http://www.aglp.org). In 1974 , as it was not found scientific enough and as it did not comply with the criteria for the assessment of mental illness, it has been removed from the book " $\mathrm{Di}$ agnostic and Statistical Manual of Mental Disorders" (TFP Committee on American Issues, 2004, p. 89).

Although homosexuals' identification as child abusers became identical with the 'sodomy' understanding in antiquity, when it comes to the modern era, this understanding has begun to be identified with the concept of 'homosexual employment'. According to this opinion, because homosexuals cannot reproduce, they secretly direct children to homosexuality and sexually abuse them (Miller, 2001).

Especially in the first years of HIV prevalence, the disease was usually diagnosed in homosexual men and the outcome of the disease has often been fatal. As a result, AIDS has begun to be perceived as a homosexual disease and this has been the general theme of the propaganda carried out (Musto, 2007). However, according to the World Health Organization (WHO) surveys, it is reported that $50 \%$ of HIV carriers are female, that is, not a large part of those who carry 
the disease. saying that half of them are male and $61 \%$ of the spread of the disease among males is due to males having relation with males (WHO, 2009).

\section{METHOD}

To purpose public relations as a defense mechanism, this study analyzed the content of anti-homosexual propaganda materials in Turkey. The materials used in the analysis are selected by purposive sampling through accessible anti-homosexual propaganda content. As described in literature anti-homosexual (homophobic) propaganda defined as conveying negative opinions against homosexuals by various propaganda techniques. As the definition reflects for assigning Public Relations as a defense mechanism, anti-homosexual propaganda activities in Turkey analyzed in terms of general themes, discourse and the reliability of facts.

In the second step, the findings of the analysis and literature compared by the researcher and after those public relations activities and methods applied the findings as a defense mechanism. Within the scope of this study the proposed defense mechanisms are not on the basis of implementation level but only suggestion level. It is expected that this study will guide future studies on similar themes.

\section{Analyzing of different anti-homosexual propaganda materials in Turkey}

Kaos GL examined the anti-gay propaganda discourse in the Turkish media regarding Lesbian, Gay, Bisexual and Transgender (LGBT) individuals. Among 3645 news, it is seen that 226 of them have the LGBT individuals' opinions and only 990 were found to be positive. News outside the category that is considered positive consist of sub-themes similar to these: "LGBT individuals are offered as sexual objects", "LGBT individuals and events are being criminalized", "Violence against homosexuality is legitimized", "LGBT individuals are being caricaturized", "Humiliating photo and visual used", "News made with the attacker's statement", "Spreading hate discourse" etc (İnceoğlu, 2012, p. 298303). As can be seen from the news example in Figure 1 , even though there is no relationship with the crime of the thief's sexual orientation, the title of the news emphasizes that a homosexual stole the clergyman's bag and they found him guilty not because of the crime he committed, but because he is gay and leads the reader in this way.
Figure 1: A screenshot From www.hurriyet.com.tr (6 April 2010) Retrived: 02.05.2018

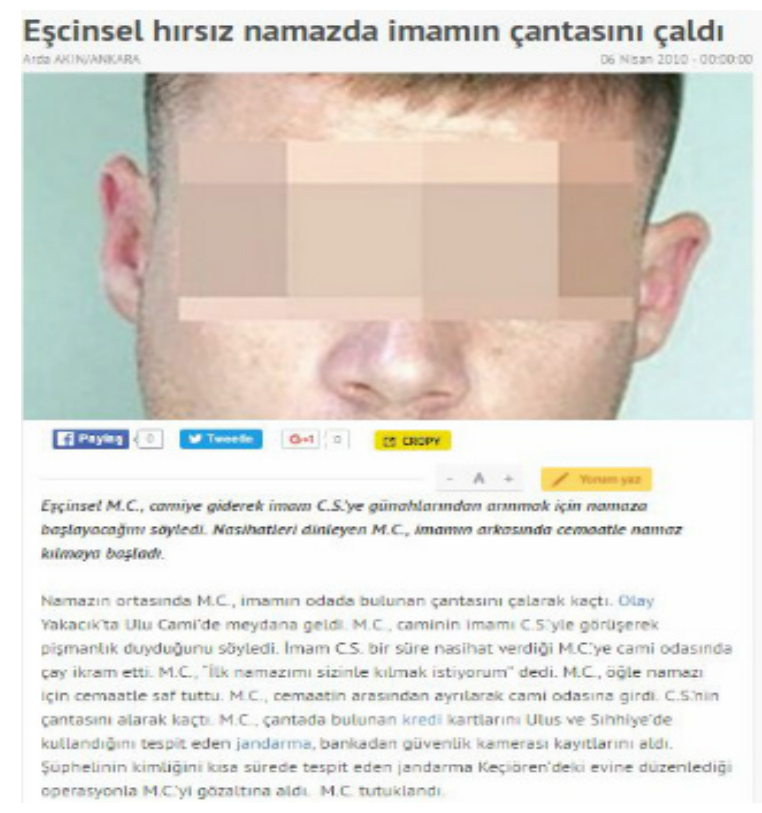

Source: http://www.hurriyet.com.tr/

As an another example, Turkish televangelist Adnan Oktar (aka Harun Yahya) -who arrested in this July on multiple charges included sexual abuse (https:// www.aljazeera.com) and his followers known by their anti-homosexual discourses. In the article (http://www. pravdareport.com/; For Turkish: http://m.harunyahya. org/) dated 12 May 2016, the following quotations summarize these views:

"Families are the fundamental building blocks of society. In order for a society to flourish and remain healthy, the family should consist of a father and a mother who are able to produce and give rise to children. However, there is a rising trend in many Western countries, which is intrinsically in contradiction to what is considered a normal society: same-sex marriage. (...)

Furthermore, many activists promote homosexuality as another human rights issue that must undeniably be protected. Some endeavor deliberately to oppose religious values and merits while some are misguidedly following them in order to be hip, modern, trendy and in tune with their notion of what a new modern culture should consist of. They are usually unaware of the damage it is imposing on society, especially on children and the young generation. Accordingly, homosexual activists use every opportunity they get in order to spread their 
homosexual lifestyles both within their communities and outside their communities. (...)

I write this article. As a matter of fact, the purpose of this article is to remind young people not to fall into this brainwashing trap and to keep the strong spiritual values to have for an honorable life; in this way the members of society who pay heed to morals will respect them in the appropriate way(...)

Considering the matter in terms of morals and ethics, we encounter a higher rate of child molestation in same-sex couple households. It is a moral obligation to protect the interests of helpless children in our society. Extensive researches show that children of same-sex parents are more likely to experience sexual confusion and to engage in homosexual activities themselves that will eventually cause them to suffer from psychiatric disorders, substance addiction, sexual assault, suicide, and sexually transmitted diseases such as AIDS. In the US alone, government investment in the domestic response to HIV has risen to more than \$24 billion per year (...)"

These statements are similar to the accusations against homosexuals shown in the previous chapters. According to Oktar and his followers, homosexuals are threats to society, have perverted minds, abusing children and sick -mentally and physcially- people. The important point for propaganda here, until the mentioned arrestments Oktar had a full-functioning TV channel (A9) for spreading his views (As an example from broadcast: https://www.youtube.com/ watch?v=DMipPxyj87E) and also had the power to distribute the leaflet shown below.

According to this leaflet, similar to above article and related propaganda activities: "Homosexuality is despicableness and can be turned away by convincement", "forbidden in all religions", "homosexuality is perversion", "it's not hormonal or genetic".

Besides this leaflet, many different anti-homosexual non-govermental organization published manifests or signed different declarations within similar accusations and prejudices (https://www.kaosgl.org, https:// www.timeturk.com, http://www.haber7.com/).

Both in Oktar's article and the leaflets, discriminatory language is clearly visible. Of course, it is not enough to have a television channel or power to distribute these leaflets for propaganda purposes.
Oktar and other anti-homosexual organizations also have the power of influencing the public by abusing "values".

Figure 2: An Anti-Homosexual Leaflet

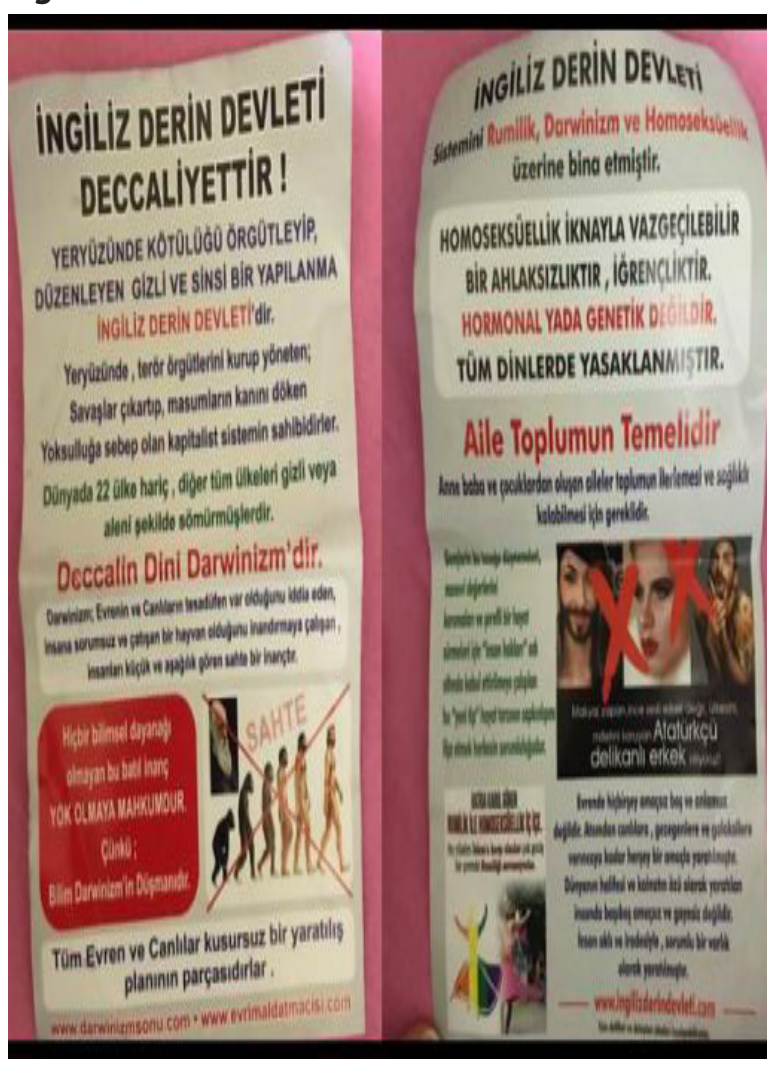

Source: Bianet.org

For an instance in above 26-line article, the following words draw attention; families -father, mother, children-, society -community-, religion, Western -Western culture-, honor, moral, brainwashing trap, molestation -abuse-, protection - helpless children-, psychiatric disorders, substance addiction, sexual assault, suicide. Although it varies from person to person most of these words have the potential power affecting emotional states or even changing them completely. The same method is used not only in articles but also in television programs, leaflets, face-to-face communication etc.

These propaganda examples show us that such a discourse can be a powerful means of persuasion. Many anti-homosexual organizations applying this discourse and its rhetorical orientations in order to collect supporters and to create an anti-homosexual perception. Furthermore, by "ideological apparatus" (Althusser, 2006, p. 87) media, politics, religion and educational institutions are actively being used as 
mediators of this propaganda, as can be seen in the above examples.

\section{Public Relations as a Defense Mechanism Against Homophobic Propaganda}

Facing these type of propaganda requires the use of crisis management processes on one hand, but in the long run in order to correct the image created in minds. Within the framework of the issue, for LGBT individuals and organizations it is very difficult to respond to these systematic propaganda activities and also to correct their images at the same time.

The first point to be emphasized is the point of institutionalization and conceptualization. There are LGBT associations and solidarity organizations in Turkey but these associations and organizations haven't got any central structure, to act within the a common discourse. Common language and discourse thought to be important for a in addition to the mass demonstrations and as well as for the persuasion. The declarations where there is no common discourse and where each association issues within their target audience, both the propagation speed rate and the impact capacity are quite limited.

When the homophobic discourse is compared with the power and propagation speed, the distribution of organizations' messages is limited to their own masses. Of course, it is also important to consider how difficult it is for "marginal" organizations to be involved in the traditional media. Nevertheless, public relations advises to determine who should be reached and / or who should be reached before any campaign plan or crisis management process is initiated. According to this, after the persons to whom the messages will be delivered are classified as internal and external, they are ranked as primary, secondary and marginal target audience according to their importance. The point that LGBT organizations should be aware of are; to classify the persons to whom they are addressed in this context and the necessity of identifying different message strategies for each classification. In this way, organizations can develop ways to defend themselves, their members and LGBT individuals, even if they are not affiliated with any group against opposing discourses, against accusations and discrimination through logical arguments and mass-oriented messages based on a solid ground.

After the target group has been classified, the research, which is one of the basic processes of public relations, comes into play. Here, "research" refers both to the issue of the agenda and to the examination of the content of messages containing counter-party accusations and prejudices in general. For example, against a statement saying that AIDS is a homosexual disease which is clearly carrying propaganda purposes, first of all, to analyze the source and the purpose of the claim put forward, then quickly gather data which will negate the claims and to deny claims through as many channels as possible seems to be the most likely scenario. But no matter how successful the defense or the refusal is, the credibility of the source of propaganda and the attitudes and beliefs of the masses can make all the efforts wasted. Thoughts considering that public relations are a "trick" emerges at this point. Accordingly, the target masses believe what they want to believe, hear what they want to hear and see want they want to see in the framework of certain prejudices (Hunt and Grunig, 1994).

The "prejudice" is undoubtedly regarded as one of the toughest challenges of LGBT individuals and organizations. Although it is not appropriate to identify a social phenomenon with the management sciences, sampling method related to the subject can be used for the adaptation of the public relations process. Reputation management, which is one of the main areas of work for public relations, is directly related to the prejudices. According to this, the names and brands which are made on the basis of positive prejudices in the minds; can provide outputs such as feelings of closeness, being preferred, forgiveness and even ignorance of mistakes at the same time may lead to lack of respect; feelings of coldness, constantly being thrown into the secondary plan, and even small mistakes may be magnified and turn into a crisis. In this context, negative prejudices are seen as one of the biggest factors in the formation of reputation. In this process, institutions and organizations which use public relations activities actively, apply corporate social responsibility, image restoration, lobbying and persuasion methods to get rid of prejudices and create a reputation. Another thing that is recommended for LGBT organizations is the prominence here. Although there is an individual effort, considering the following target audience sensitivities which may have a significant impact on the reshaping of homosexual perception in the minds, it is an activity that can make a great progress in an institutional framework and when public relations are applied based on the campaign process. 
Likewise, lobbying activities can be considered as an effective strategy that can be used in this process. Although the demonstrations and the public power are seen as effective activities in terms of agenda setting, when the political mechanisms and authorities are under the influence of the discourse of propagandists, they can limit the activities of organizations to a wide range (Dozier and Grunig, 1992, p. 400). The fact that the people in politics are the direct source of propaganda is an important problem especially for LGBT organizations. Organizations which are already struggling with prejudices face the danger of receiving political will against them. In this case, lobbying activities are in place, local and national political authorities are reached, and sensitivities about the issue play an important role. Taking steps to ensure mutual benefit and determining the future approach are important factors here.

Dean E. Mundy's (2013) research on state-based LGBT advocacy organizations shows a successful lobbying activity example. Mundy's research results are as follows:

State-based LGBT advocacy organizations shape their communication strategy (...) from the ground up, not from the top down. Their Agenda comprises campaigns that use a local-first strategy to pursue inclusive policies regarding issues of non-discrimination, hate crimes, safe schools, and relationship recognition (...) The philosophy posits that building a critical mass of support for these issues at the local level (...) provides momentum for change at the state level (...) The goal is to craft positive, non-combative messages that communicate the importance of diversity, the breadth of diversity within the LGBT community, and how that diversity reflects society as a whole. Accordingly, these organizations seek local LGBT individuals and allies to serve as organizational spokespersons who-in conveying their locally specific, authentic, personal stories-are able to emphasize how LGBT issues are community issues (Mundy, 2013, p. 387).

Except for minor exceptions (As an example: https://www.bbc.com/turkce/live/haberler-turkiye-41926807) in Turkey, there are no successful examples or approaches as above. However, ground up locality strategy and non-combative message selection in Mundy's work grants effective guides for public relations.

If the public relations is examined within the framework of discipline issues in a more detailed manner, it can be seen that the roles of public relations are convincing, representative, innovative, information provider, reputation manager and relationship builder (Hutton 1999). Considering the propaganda, each of these roles can be considered as guiding to LGBT organizations in protecting against adverse effects and even in changing the situation in their favor. Within the framework of Public Relations based on the cause, persuasion; especially in societies raised within a culture of fear, refers to the process of putting the various theories into practice against the system of thought that reproduces itself through the inoculation of beliefs that constantly nourish their fearsome origins. This process, which can also be used for protection against propaganda, may follow the way with the presentation of some of the arguments on solid foundations, sometimes the use of faces that have the trust and respect of the target audience and sometimes the way to correct distorted messages given to them through their own beliefs. Providing correct information against manipulative messages with the help of persuasion theories is an important influence on the development of an accurate defense mechanism.

Although these strategies may be effective in the development of preventive and defensive mechanisms against counter-propaganda activities, pro-active and re-active understanding, which is one of the most important factors of public relations, must be dominant during the process (Jo, 2003, p. 400). Accordingly, within the framework of problem management with pro-active approach, propaganda activities must be addressed before they turn into crises which will trigger inflation in the public and preparations should be made for LGBT organizations and opposing discourses that are welcomed by individuals in a loop with the support of a team with predictive competence and preventions must be taken. With the re-active approach, it is expressed to overcome the developments which may cause destructive results made by all the preparations with crisis management of public relations, with crisis communication processes with the help of experts.

\section{CONCLUSION}

It is observed that anti-homosexual propaganda showing itself with feelings of prejudice, hatred, repulsion against LGBT organizations and individuals. And the reasons of propagandist could be psychological, cultural or religious. Propaganda activities done by 
humiliating and degrading expressions against homosexuals with religious, medical or moral reasons. These negative referrals and false accusations regarding homosexual desire and association are clearly observed throughout history and show differences from culture to another culture.

It has also observed that negative propaganda directed against homosexuality, was carried out in the themes considering homosexuality is not natural, it is related to child abuse, as a sin and/or HIV as a homosexual disease. However these allegations do not fully reflect the facts or are totally distant. In selecting the sources of these inferences, attention has been paid to foreign literature but and examples taken within Turkey.

In the continuation of the study, the question of "how public relations could be used by LGBT organizations as a defense mechanism against propaganda?" is answered under the public relations roles such as persuasive, representative, information provider and founder within the framework of management practices and communication processes. According to this, within the framework of pro-active and re-active approaches, it is seen that different strategies and implementation plans should be determined.

The elements of public relations such as persuasion, research, image management, crisis communication and message strategies are very important for minimization of the effects of propaganda which is spreading very quickly also to protect and be protected against this discourse is possible with communication-based public relations methods and practices. Also it is important to access the political authorities together with the public power, it is important to reach the external target masses together with the internal target masses and making classification in this audience for organizations. 


\section{REFERENCES}

"The Declassification of Homosexuality by the American Psychiatric Association", http://www.aglp.org/ gap/1_history/ Retrieved:: 11.04.2018.

Althusser, L. (2006). Ideology and ideological state apparatuses (notes towards an investigation). The anthropology of the state: A reader, 9(1),pp. 86-98.

Dailey, T. J. (2002). Homosexuality and child sexual abuse. Insight N, 27.

Dozier, D. M., \& Grunig, L. A. (1992). The organization of the public relations function. Excellence in public relations and communication management, 395-417.

Grunig, J. E., \&Hunt, T. (1984). Managing public relations. Harcourt Brace Jovanovich College Publishers.

Haggerty, G., \& Zimmerman, B. (2003). Encyclopedia of lesbian and gay histories and cultures. Garland Science.

Howard, J. (Ed.). (1997). Carryin'on in the Lesbian and Gay South. NYU Press.

http://m.harunyahya.org/tr/Makaleler/221045/ Homoseksuellik-(cinsel-sapkinlik)-hakkinda-insanlardan-gizlenen-onemli-gercekler, Retrieved: 28.07.2018

http://www.haber7.com/guncel/haber/200574340-stk-lgbt-yuruyusune-karsi-bildiri-yayimladi), Retrieved: 28.07.2018

http://www.hurriyet.com.tr/escinsel-hirsiz-namazda-imamin-cantasini-caldi-14327928 Retrieved: 10.04.2018.

http://www.pravdareport.com/opinion/columnists/12-05-2016/134394-homo sexuality-0/, Retrieved: 28.07.2018

https://web.archive.org/web/20071218155700/ http://www.frc.org/get.cfm?i=IS02E3， Retrieved: 11.04.2018.

https://www.aljazeera.com/news/2018/07/turkey-arrests-televangelist-adnan-oktar-multiple-charges-180711105001781.htmli, Retrieved: 28.07.2018

https://www.bbc.com/turkce/live/haberler-turkiye-41926807, Retrieved: 30.12.2018

https://www.ctvnews.ca/sports/ahead-of-olympics-russia-raises-anti-lgbt-rhetoric-1.1562570, Retrieved: 28.07.2018

https://www.kaosgl.org/sayfa.php?id=26307 Retrieved: 28.07.2018

https://www.timeturk.com/uhim-escinsel-lobilerinin-hedefi-aile/haber-172993, Retrieved: 28.07.2018 http://bianet.org/bianet/nefret-soylemi/199375-izmir-ve-ankara-da-homofobik-bildiri-dagitildi, Retrieved: 28.07.2018

https://www.youtube.com/watch?v=DMipPxyj87E, Retrieved: 28.07.2018.

Hunt, T., \& Grunig, J. E. (1994). Public relations techniques. Harcourt Brace College Publishers.

Hutton, J. G. (1999). The definition, dimensions, and domain of public relations. Public Relations Review, 25(2), 199-214.

İnceoğlu, Y. (2012). Nefret söylemi ve-veya nefret suçları. Ayrıntı.

Jo, S. (2003). The portrayal of public relations in the news media. Mass Communication and Society, 6(4), 397-411.

McCormack, Marck (2013). The Declining Significance of Homophobia. Oxford University Press.

Micheler, S. (2002). Homophobic propaganda and the denunciation of same-sex-desiring men under National Socialism. Journal of the History of Sexuality, 11(1), 105-130.

Miller, Tim. Taking on the Antigay Censors, https://web. archive.org/web/20050309010753/http://www. advocate.com/html/stories/857/857_outlaw.asp Retrieved: 11.04.2018.

Mundy, D. E. (2013). The spiral of advocacy: How statebased LGBT advocacy organizations use ground-up public communication strategies in their campaigns for the "Equality Agenda". Public Relations Review, 39(4), 387-390.

Musto, M. (2007). La Dolce Musto. Carroll \& Graf.

Renzetti C.M., Edleson J. L. (2008). Encyclopedia of Interpersonal Violence. SAGE Publications.

Stangor, Charles (ed.) (2000). Stereotypes and Prejudice: Essential Readings. Philadelphia, Pa.: Psychology Press. ISBN 0-86377-588-8.

TFP Committee on American Issues. (2004).Defending a Higher Law: Why We Must Resist Same-Sex "Marriage" and the Homosexual Movement. The American Society for the Defense of Tradition, Family and Property

World Health Organization (2009). Gender inequalities and HIV. Geneva: WHO.

Zimmerman, B. (2000). Lesbian histories and cultures: An encyclopedia (Vol. 1). Taylor \& Francis. 